\title{
PSYCHOLOGICAL ACCOMPANIMENT OF THE STUDENTS' HEALTH RECREATION PROCESS IN THE PSYCHOLOGICA FIELD
}

\section{Kichuk A. V.}

\section{INTRODUCTION}

In the context of personality development psychology, adolescence (in particular, its second period, that is, 17-21 years) coincides with the stage of student status acquisition. Scientists mainly share the theoretical model of socio-normative periodization developed by D.I. Feldstein to emphasize the features of personality formation in the context of all stages of ontogenesis - from fixing self-identifications through self-affirmation to self-determination and self-realization ${ }^{1}$.

Among the many approaches that have developed in modern psychological science, scientists are of considerable interest to those that allow us to expand the boundaries of our "knowledge of ignorance." Especially when it comes to the multidimensional activity of modern man; there is no exception to the interpretation that in general life is from the point of view of psychology. In connection with the above, attention is drawn, in particular, to the scientific discussion regarding such "polar trends in the methodology of science" which are regarded (O. Gasmolov, O.D. Shekhter, O. M. Chernorizov) specialization and universalization of cognition $^{2}$.

The present day brings to the fore the eternal questions of human vitality, the central place of which is health (physical, social, psychological, spiritual).

Mostly, the phenomenology of health is studied as a subject of medical and social research. After all, according to the encyclopaedic interpretation, health is a natural state of the human body, characterized by poise in relation to the environment. The researchers, directly or indirectly studying the content-related characteristics of health, are still trying to

\footnotetext{
${ }^{1}$ Ермолаева М.В. Психология развития : учебное пос. - 3-е издание, стереотипное. - Москва : МПСИ ; Воронеж : МОДЭК, 2006. - 376 с.

${ }^{2}$ Маслоу А. Психология бытия. - К.: Ваклер, 1997. - 304 с.
} 
agree on a clear definition of a basic concept. Thus, the statute of the World Health Organization contains the following definition: "Health is a state of complete physical, spiritual and social well-being, and not just the absence of diseases and physical defects." In the context of psychological and pedagogical problems, various aspects of the physical, spiritual, social and psychological health of an individual are actively being studied. Therefore, the idea of the corresponding "flower petals" of a healthy person has already been formed. But even the fundamental developments of researchers on the phenomenology of health (Bilych G.L., Nazarova L.V., Popova S.V. and others) did not provide a universally recognized scientific position on the content of the concept of "health". For example, the convincing conclusions of the researchers include depriving the emphasis on the mainstream meaning of "well-being"; the importance of human ability to adapt to the environment; recognition a person to be healthy as one who has no diseases, physical defects; the appropriateness to see in health both qualitative and quantitative characteristics (recognizing that it is fundamentally important to measure its degree in terms of the breadth of the adaptive capabilities of the organism), etc. Of particular interest to health researchers is the scientific potential (in particular, of V.P. Kaznacheyev), where it is proved, on the one hand, the dynamism of a healthy state, and on the other, the importance of a person's ability to "optimal practice, social activity provided a maximum life span". P.I. Kalyu, as a result of the analysis of professional literature (which represents his work "Essential characteristics of the concept of "health" and some issues of restructuring health protection: overview information") comes to the conclusion that it is legitimate to distinguish between the most common concepts: medical, in which the leading a characteristic of health should be considered the absence of diseases and their symptoms; biomedical which recognizes the absence of a subjective feeling of "ill-being" - a basic parameter of health quality; biosocial, where social markers are recognized as the dominant features; value and social, according to which health is conceived as inherent value. The latter concept was determined by researchers as constructive for the context of studying the subject specifics of the social and humanitarian sciences (in particular, psychology - experimental, social, health psychology, 
developmental psychology, pedagogical psychology), in terms of human behaviour which is connected with his or her health ${ }^{3}$.

Despite the scientific research on the phenomenology of health available in psychological science, there is still a lack of consistency in scientific ideas about the psychological health of a person at different stages of ontogenesis.

Of fundamental importance for our study, we regard the position of O. Khukhlaueva, who believes that since a person builds relationships based on subjective experience, it is precisely at the age of 23-25 years old that he or she "receives" this access given the acquired spiritual powers and opportunities, and this "gives him or her an opportunity to carry out spiritual activity" ${ }^{4}$. An attempt to determine the basic characteristics of a student personality's psychological health in particular, makes notable O.S. Shtepa's studies. The researcher refers psychological resourcefulness, which was interpreted through a person's spiritual abilities, to those revealing the "individual's life-purpose experience and the value-based attitude to others", 5 .

Therefore, we can assume that it is in the indicated age period that a personality acquires the ability to reveal the nature of his or her own relations with the environment, to determine the position in relation to the "not-Self", that is, to others.

It is known that the basic idea of both existential and humanistic psychology is the recognition of subjective activity as an internal determinant of human life. Therefore, it can be assumed that psychological health acts as a parameter of "value" and "sense". The latter, in the context of axiological problems, for example, B. Bratus' specifies with a "personality's semantic sphere" construct. O. Ball - with a "semantic mindset", V. Chudnovskyi - with the "optimal sense of life", D. Leontyev with " life-purpose orientation", V. Frankl - with "sense creating activity", Leontyev - "personality sense". At the same time, despite the diverse accents in the conceptual interpretation of the value-semantic determination of human life, it is completely obvious that we are talking about a possible measurement of its psychological health, making up the

\footnotetext{
3 Бочавер А., Ступак Р. XXIV Европейская конференция по психологии здоровья «Здоровье в контексте». Психологический журнал. - М.: Наука, 2011. Т. 32, вип. 2. С. 116-118.

${ }^{4}$ Хухлаева О.В. Психология развития: молодость, зрелость, старость. - М.: Изд-ий центр «Академия», 2002. $-208 \mathrm{c}$.

5 Штепа О.С. Особливості психологічної ресурсності осіб 20-25 років з різним статусом ідентичності // Наука і освіта. - 2013. - № 7. - С. 204-208.
} 
subjective indicators. And the latter is related to attitude; it realizes an incentive function and performs a regulatory role regarding the behaviour and manifestation in all sorts of human activity.

In the outlined perspective, the philosophers' opinion that precisely values are decisive in the "upper boundary of an individual's social claims" seems interesting to us".

So, the axiological approach acquires exceptional explanatory value in the process of deepening of scientific ideas about the phenomenology of an individual's psychological health in the corresponding age period, of course, taking into account the established ones (O. Zdravomyslov, Z. Karpenko, G. Rikker, M. Rokych, M. Chavchavadze and others) dominants of this approach. In our understanding, its constructiveness is also associated with the potential of integrating the natural science and humanitarian methodologies. That's why we see important guidelines for expanding established ideas about the psychological health of an individual in A. Maslow's methodological value position that "moving towards the psychological health of an individual means approaching a society based on spiritual values, approaching social harmony"7 as. The foregoing sets methodological guidelines for the selected research approach.

\section{The psychological health of adolescent personality as a subject of modern scientific knowledge}

The analysis of both reference and special literature testifies to the interconnection of the concepts of "health" and "individual meaning of life". Researchers (O.O. Korolkov, V.F. Serzhantov) have proved that it is advisable to proceed from the characteristics of the "personality health model." In their opinion, structurally, such a model is represented, firstly, by the attitude of a person to his or her own body; secondly, the personal degree of understanding of health and conservation goals; thirdly, knowledge of the laws of the functioning of the body and the degree of volitional regulation; fourthly, one's own attitude to diseases, the level of activity aimed at overcoming a diseased state; fifthly, the expressiveness of motivation in the healing process. Therefore, based on the personal model of health, we can assume the nature of strategies and tactics produced by a person during his life's journey.

\footnotetext{
${ }^{6}$ Кремень В.Г. Освіта має визначити розвиток духовності й культури //Креативна педагогіка. - 2011. № 4. - C. 11-12.

${ }^{7}$ Маслоу А. Психология бытия. - К.: Ваклер, 1997. - 304 с.
} 
A somewhat different research approach is proposed by S.Ya. Chykyn and G.I. Tsaregorodtsev, in particular, believing that health is a manifestation of the integrity of the individual. Such position coincides with our understanding of the origins of a special state of personality psychological health. So, the scientists by the context of "health" for a reason consider a "norm" and "disease", stating the following: it is impossible to reduce health only to a physical state. This position has been recognized in psychological science and practice ${ }^{8}$ through the approval of the imperative $f$ the equally important role of psycho-emotional equilibrium, the latter being understood as a person's "psychological health". At the same time, the researchers highlight the etymology of the English word "health", which comes from the Anglo-Saxon word "whole", and some of them (in particular, Yu. Dorovantu, Z. Pavdid, P. Penchu) affirm that it is appropriate to consider health to be the quality of life, recognizing the interconnectedness, interdependence and intercondi-tionality of the individual's physical condition, his mental manifestations, emotional reactions and the life social environment; moreover, it is affirmed that the personality's behavioural model "adapts" to a harmonious and integrated set of relationships and influences between the individual and society.

The analysis of scientific sources shows that in scientific vocabulary the term "psychological health" is often replaced by others. If we analyse the thesis researches, then there is a ground to note that it is said about a "norm" and a "pathology" (Dushka O.O.), a personality's stress resistance (Korolchuk O.M.), psychological well-being (Oleksandrov Yu.M.).

As a result of the analytical work done, it has been found out that some of the problematic issues of psychological health and the author's vision of their solution contain O.V. Zavgorodnya's developments. We consider the researcher's position to be constructive, in particular in such perspectives:

- the outline of the content of the "psychological health" concept represented by: a high level of formation of conscious self-regulation, rational-volitional sphere; these components provide both the possibility of a person's social adaptation, as well as a "free underpressed state of the emotional sphere", activity of mental processes unconscious by a person; his or her ability to deep feelings and intuition is based on the outlined components;

\footnotetext{
${ }^{8}$ Психология здоровья / Под ред. Г.С. Никифорова. СПб: Питер, 2003. 607 с.
} 
- implementation of the revision of the concepts of "mental" and "psychological" health: psychological health becomes possible with the availability of mental health; contradictions are possible between the designated phenomena despite their relative autonomy;

- providing the psychological health of a person with the characteristics of a dynamic process - firstly, due to the interpretation of the said personality neoplasm as a "dynamic integrity", secondly, insisting on such a characteristic of a psychologically healthy person as the "pulsation" of harmonious and disharmonious states; thirdly, illustrating the trajectory of movement in this way: a psychologically healthy person combines certain features of the mentally normal (in the traditional sense) and the features that are not characteristic of this person (vulnerability, activity of unconscious mental processes, the ability to deep feelings) which "under certain conditions" can lead to mental destabilization",;

- determination of the criteria for the psychological health of a person, irrespective of age specifics, namely: a sensitive-interested attitude to one's own identity and other living beings; pronounced cognitive and creative activity; self-motivation and constructiveness of life practice; beneficial effects on the environment;

- The attempts to determine the scientific status of the "psychological health" concept through the construct "psychological ill-being", the originality of which is associated with a person's choice of a passive life strategy.

It is obvious that the implemented study broadens the established understanding of the phenomenology of human psychological health through the definition of new outlines of this phenomenon, as well as the search for the limits of intersection with mental health, emphasis on measurements, at which certainty in the diagnostic tools is possible.

However, despite a completely obvious productivity of O.V. Zavgorodnodnya's research position of, we nevertheless agree that in this position the interpenetration of two different phenomena is quite clearly traced psychological health and moral health. The researcher claims the following: "we distinguish between the concepts of "psychological health" and "personality maturity", although we consider them interrelated; "Psycho-

\footnotetext{
9 Завгородня О.В. Питання збереження психологічного здоров'я: визначення, критерії, умови збереження. 2006. № 3(52). С. 87-96.
} 
logical health is the pre-condition of achieving personal maturity, and personal maturity contributes to the preservation of psychological health", ${ }^{, 10}$.

In connection with the aforementioned, those scientific approaches that have explanatory power on such a complex phenomenon as the psychological health of an individual appear to be of great research interest. O.V. Shuvalova's point of view seems convincing to us, who claims that it is appropriate to think over this personality state simultaneously in the perspective of two approaches: person-cantered and sociocentric; this is motivated, on the one hand, by the obvious intersection of such approaches in explaining the spiritual value of a person, and on the other, by helping to develop an "anthropocentric standard of health". Therefore, the researcher notes not without reason that psychological health acts as a state that characterizes the process and result of the "normative development of subjective reality within the framework of individual life" ${ }^{\text {"11 }}$. In addition, we consider to be substantial the following clarification made by O.V. Shuvalov: the "maximum" of psychological health is the integral - unity, completeness and integrity - of the vitality and "humanity" of a personality.

Our interest was the age period of a personality at the stage of acquiring professional identity by him or her, namely - in higher school conditions. The outlined plane of comprehension of the above-mentioned aspect of the problem of psychological health of a personality is conditioned, on the one hand, by the specificity of the influence of the educational process and its educational and professional activity on the relevant components of the determined personal property; on the other hand, the analysis of numerous empirical data obtained by researchers (in particular, Havrylyuk I., Kuznetsova O., Ryabchenko N. - Ukraine; Perera H., Mcilveen P., Oliver M. - Australia; Deasy C., Coughlan B., Pironon J., Jourdan D., Mannix-McNamara - Ireland; Enns A., Eidridge G., Montgomery C., Gonzalez V. - the USA), regarding the psychological health problematic field of today's student youth.

So, in our opinion, the structural and component composition of "psychological health" concept and the uniqueness of certain components of such a personal characteristic (like the emotional component) becomes more

\footnotetext{
10 Завгородня О.В. Питання збереження психологічного здоров'я: визначення, критерії, умови збереження. 2006. № 3(52). С. 87-96.

11 Шувалов А.В. Гуманитарно-антропологические основы теории психологического здоровья. Вопросы психологии. 2004. № 6. С. 18-33.
} 
fully possible under the conditions of "specificity" of age. This acquires special significance, since many problematic issues of modern psychology are directly or indirectly associated with the "biological - psychological social" plane by researchers, and when it comes to a multi-aspect and multilevel psychological phenomenon, it is recognized that, as a rule, the development of any phenomenon does not stop during life, is not formed in a certain age period of a person once and for all. For example, setting the goal to explore the processes of gender identification and the formation of gender identity in the ontogenesis of an individual, researchers emphasize the importance of choosing a healthy gender-role behaviour ${ }^{12}$.

On the whole, it can be assumed that despite the importance of being aware of those personality neoplasms that are caused by the specifics of his or her age (M. Akimova, I. Dubrovina, V. Voytenko, V. Karpenko, A. Khlivna, etc.), there are still grounds to admit that the boundaries of a personality's age who identifies himself with the status of students, are relative and conditional. This is caused by an objectively existing circumstance, because a personality realizes his or her intention to become a student depending on the age period when the decision about professional choice is made. To the abovementioned let us add that, based on the nature of such a phenomenon which appears to be psychological health of a personality in student years, it is expedient to conceive it by its basis - the sovereignty of psychological space. As the researchers note, it makes sense to consider psychological sovereignty not only as a condition, but also as a result of adaptability, maturity and productivity of a person; moreover, such "harmonious success" uses the "language of the environment" - the language of "the interaction of individuality and society" ". Therefore, it is possible to assume that the state of psychological health of the student's personality is a kind of indicator of "control" and "self-control".

\section{Taking into account the emotional determination of students' psychological health is recreational psychology imperative}

Psychological health determinants are still the subject of scientific discussion, a personality's psychological health acts as a holistic entity which involves a certain balance of properties and processes. Therefore, it

\footnotetext{
12 Кікінеджі С. Гендерна ідентичність в онтогенезі особистості: монографія.-Тернопіль: Навч.книгаБогдан, 2011. - $400 \mathrm{c.}$

13 Гаврилюк I. Емпірична експлікація суверенності психологічного простору в показниках соціального контролю особистості // Психологічні перспективи. - Вип.33. - Луцьк, 2019. - С. 49-65.
} 
makes sense to perceive in a personality's health in the psychological sphere a dynamic personal property. We share the opinion of researchers who note the usefulness in the outlined psychological phenomenon to distinguish between the hierarchy of certain levels, in particular, from the perspectives of "mental", "subjective" and "individual". Given the abovementioned, as claimed by T.D. Dancheva, it is advisable to distinguish several levels of psychological health of a personality. In particular, at the mental level, the educational system also acquires the actualization of personality, on the subjective - vitality, and on the individual - adaptability ${ }^{14}$.

In our understanding, the personality's psychological health acts as his or her integrative property, where exactly the emotional component has comprehensive and systemic role. The fact is that all sections of psychological science are connected with emotions; this phenomenon also permeates any personality's activity, penetrating into psychological processes. S.L. Rubinstein's opinion is perhaps the most authoritative in this regard: "The point is not that emotion is in unity with intellect or thinking with emotion, but that thinking itself as a real psychological process is already the unity of the intellectual and emotional, and emotion is the unity of emotional and intellectual" 15 .

Scientists who study certain vectors of the personality's emotional sphere (Emons P., Kyrylenko T., Lushin P., etc.), are unanimous in recognizing the fact that it is in emotions that one recognizes through experience both the significance of the environmental phenomena and the weight of "one's own". In addition, a positive correlation between emotional intelligence and personality openness to interaction in interpersonal relationships has been established (Caruso D., Meyer J., Myloslavska O., Solovey P., etc.). Therefore, the researchers conclude that emotional intelligence, as a psychological phenomenon is directly related to the personality's friendliness.

The founders of the emotional phenomena psychology (Vilyunas V.K., Grat N.Ya., Isard K.E. and others) have proved that they have a dual character, as well as the peculiarity of the colour with which the subject reflects. At the same time, in connection with the comprehension of the emotional component of the psychological health of the personality, we

\footnotetext{
14 Данчева Т.Д. Типология психологического здоровья личности // Наука і освіта, 2012. - № 3. C. $50-54$.

${ }^{15}$ Рубінштейн С.Л. Проблеми загальної психології. - М.: Педагогіка, 1973. - 424 с.
} 
also consider such comments important. Firstly, emotions act as one of the forms of existence of personal sense; moreover, it has been proved that both systems of terminology - "emotional" and "semantic" - in psychology "describe" the same phenomenon, are interchangeable, although "sense" has a more explanatory character, and "emotions" are descriptive ${ }^{16}$. Secondly, emotional phenomena have an "external" effect on the general course of the psychological process through the functions they perform (emphasis, memory, synthesizing, inducing, creating an "affective trace"), which are interrelated.

The abovementioned, of course, affects the basic dimensions of health in general: as a fact, as a norm, as a value, as an object of scientific knowledge. In addition, the indicated construct acquires certain specificity, taking into account both the interpretation of the personality and the level characteristic of his or her development. As regards the latter, according to S. Maksymenko, at least three levels should be distinguished, namely: on the first level, the reflection of one's own inner world is absent, on the second - events are already planned by the personality and their consequences are predicted, their own environment is formed, and on the final level the subjective measurement of not only one's own life path takes place, but also of one's own inner world ${ }^{17}$. At this, experience is recognized as the "correlate of the existence of the inner world"18. Therefore, the specified forms an explanation of the origins of psychological health emotional characteristics as an integrative personality characteristic. Indeed, modern reference sources define experiences both as an emotionally coloured state of a subject, and as an internal signal with which a person "realizes the personal significance of events", and as a form of subject activity aimed at rethinking one's existence. Therefore, it seems possible to re-evaluate the importance of the fundamentally important remarks of scientists in relation to the specifics of emotional phenomena ${ }^{19}$. It is, firstly, about understanding the general and diverging in the "emotional" and "semantic": they describe the same phenomenon in psychology, and therefore are considered interchangeable; at the same time, it's still appropriate to understand that "sense" basically acquires an

\footnotetext{
${ }^{16}$ Вилюнас В.К. Психология эмоциональных явлений - М.: Изд-во МГУ, 1976. - 143 с.

${ }^{17}$ Максименко С.Д. Генезис существования личности - К.: Изд-во ООО «КММ», 2006. -240 с.

${ }_{18}^{18}$ Максименко С.Д. Генезис существования личности - К.: Изд-во ООО «КММ», 2006. - 240 с.

19 Чебикін О.Я. Становлення емоційної зрілості особистості: монографія / О.Я. Чебикін, І.Г. Павлова. - Одеса: СВД Черкасов, 2009. - 230 с.
} 
explanatory, and "emotional" - descriptive character. Secondly, the recognition of the scientifically established fact that emotional phenomena realize a specific function in the process of satisfaction by the subject of his needs - experiences, add "decorations" to the image of the needs surrounding the object and thereby "turning them into motives", (we are talking, according to Vilyunas, about leading emotional experiences or motivating ones), as well as about those experiences that arise already in the presence of leading motivations, originating in the process of internal or external activity. Therefore, - these indicated emotional phenomena express the personality's corresponding formation to the conditions of activity; scientists mark them as "derivatives" 20.

Taking into account the observations made by scientists, it seems fundamentally important to re-evaluate the fundamental groundwork in this regard for some representatives of classical psychology. In particular, we are talking about the work of N.Ya. Grot (1879), who was able to analyse the long-term experience of researchers (from the ancient Greek period to the 19th century) in the aspect of the dual nature of emotional phenomena and the drawbacks of reducing real emotions to subjective emotional experiences, and then, to investigate the specificity of the emotional component, in particular, in such a complex psychological phenomenon as personality's psychological health. We believe that the designated gets considerable significance given the position among researchers regarding the understanding of the emotional segment and the mental (not psychological) one in particular, of students' health specifically. In an attempt to determine the problematic issues related to the emotional segment of the psychic as a "qualitatively new, non-world-complex system", we relied on the scientific achievements of O. Prokhorov, where the category "mental state" appears in the format of the unity of the subject's experience and his or her behaviour (deeds, actions, reactions); moreover, the scientist, while considering experiences as a basic characteristic of a mental state, differentiates experiences, emotions and feelings, considering the former much broadly than the latter ${ }^{21}$, because experiences are not limited to the affective sphere, but are connected with the activity that induces them, with everything that is conditioned by psychological experience. In this perspective, the proposed three-chain

\footnotetext{
${ }^{20}$ Вилюнас В. К. Психология эмоциональных явлений - М.: Изд-во МГУ, 1976. - 143 с.

${ }^{21}$ Прохоров А.О., Валиуллина М.Е., Габдреева Г.Ш., Гарифуллина М.М., Менделевич В.Д. Психология состояний: Уч. пос. / Под ред. А.О. Прохорова. - М.: Изд-во «Когито-центр» - 623 с.
} 
system of determination of mental states ("personality - situation personal meaning") is notable for constructiveness because the life activity situation is considered as the main reason that stimulates the mental state, and, using psychological terms, the functional structure "affect + emotions + feeling" reflects the function of psychics reactive regulation ${ }^{22}$. So, the researchers ${ }^{23}$ see at least the following things in the modern students' mental health: this category of Ukrainian youth (and according to the established empirical data, $18 \%$ of them) are characterized by overestimated indicators precisely in the context of "emotional psychological problems". To the abovementioned we shall add the following: the students' problems associated with the emotional sphere are referred to by researchers as "pathopsychological symptoms", and, detailing the results of American, Dutch and German scientists, they note empirical data on the already (and not mental) psychological health that are closest to the aforementioned students (in particular, a statement of the trend that every third student has reason to be classified as at risk of psychological maladaptation).

Therefore, in the plane of universally recognized by scientists, the exceptional importance of psychological health as a personal property, which is marked through weighty, key and cross-cutting parameters of a person at any stage of his or her life (for example, according to I. Dubrovina, is "an indicator of a person's normal development", and according to V. Lishchuk - "the most appropriate measure of individual and social development"), the theory of psychological health has not yet been developed. Academic science has not formed yet the generally accepted opinion about the system-forming phenomenon in the structure of psychological health as a complex personality formation, where emotional insensitivity is generally recognized as an indicator of a low level of manifestation.

Studying the issue of the emotional sphere as a whole causes increased interest in the works of those scientists who distinguish certain vectors in $\mathrm{it}^{24}$. We are talking about the relevance of studying the

\footnotetext{
22 Прохоров А.О., Валиуллина М.Е., Габдреева Г.Ш., Гарифуллина М.М., Менделевич В.Д. Психология состояний: Уч.пос. / Под ред. А.О. Прохорова. - М.: Изд-во «Когито-центр» - 623 с.

23 Карпенко В., Миколайчик М., Войтенко В., Мединська Ю. Сучасний стан психічного здоров'я студентської молоді : емоційна, міжособистісна та рольова сфери // Практична психологія та соціальна робота. - 2012. - № 11. - С. 2-8.

${ }^{24}$ Кириленко Т. Емоційна сфера особистості: вектори вивчення // Вісник Київського нац. ун-ту ім. Т. Шевченка. Психологія. - 2018. - № 1(8), - С. 26-29.
} 
emotional sphere of the psychics of a person to keep in the circle of research attention vectors such as: 1) the very creation of emotions and feelings (emotional exchange) 2) modality, the intensity of emotional experiences is a level sensitive manifestation; 3) emotional readiness of a person to change (emotional capabilities, emotional experience) 4) emotional self-knowledge (emotional intelligence, emotional competence as a person's ability); 5) spiritual experiences (such as mercy, sympathy, love, forgiveness). The outlined above guides the process of studying the personality's emotional sphere in general and the outline of the plane and the substantive content of this sphere in regards to students.

The study and generalization of the scientific heritage of scientists exploring the emotional world of a personality indicates, firstly, the appropriateness of distinguishing such a world in terms of its emotional typology (emotional, sentimental and passionate). So, it is recognized that the process of personality development, in fact, is a process of development of his or her feelings. And here it is important to speak mainly about the culture of the manifestation of one's own experiences, and not their containment. Indeed, the experience convinces: if unedited emotions accumulate, then with a high degree of probability it is possible to predict the disorganization of the personality in unexpected situations in life. And this, of course, affects his or her psychological health.

Secondly, about the appropriateness to distinguish by segments between romantic, altruistic, gnostic, active, communicative and aesthetic emotions and feelings by the state of the emotional sphere development (in particular, taking into account its emotional orientation). At the same time, it is considered important to take into account the probability of the existence of individuals with an undeveloped emotional sphere, who perceive the surrounding world as hostile, displaying an "unscrupulous position".

Thirdly, the generally accepted conclusion among psychologists is the conclusion that each person has precisely his or her own "emotional repertoire"; moreover, throughout life, a person is dominated by various emotional states (such as uplift, oppression, excitement, etc.), although it is advisable to consider such a form of emotions as mood an indicator of a person's temperament.

Taking into account even the aforementioned, an opportunity is already being created for determining at least two remarks: the emotional 
component of such a many parametric phenomenon as what appears to be psychological health is rightfully interpreted as one of the important ones; the preservation and optimization of the psychological health of the individual, in particular, the age stage of growing up, becomes possible only if the emotional and personal characteristics of it are taken into account. Therefore, the issue of the characteristics of the personality's psychological health emotional signs as well as those basic ones from their totality, which are characteristic of the state of health specifically to students in the psychological field, is being actualized.

Indeed, it is precisely through the emotions that a person finds sources of feedback with reality to determine his or her place in it; thanks to emotional contact with another, such a development mechanism as reflection is formed; outside of emotional contact, the "truth" of the transfer of moral experience becomes impossible. So, the abovementioned strengthens the theoretical and empirical significance of the process of researching precisely the personal emotional characteristics of psychological health. The imperative is the recognition of reduction of negative emotions but not the rejection of them.

In this context, an empirical study aimed at proving the importance of special emotional learning for students in a modern university ${ }^{25}$ attracts attention. In addition, the outlined was not considered by researchers as an end in itself, but to elucidate the indirect effect of critical thinking regarding self-regulation and social emotional learning of students. Thus, it has been experimentally established that the influence of self-regulation on the initiative of social emotional learning is mediated by the personality's critical thinking. Therefore, the acquired new data on the phenomenon of self-regulation - the ability to control oneself on the basis of and perception of one's own psychological states and behaviour - its influence (direct and indirect) on emotional learning ${ }^{26}$. Such a comment acquires great practical-oriented significance, because it allows you to direct a methodical search for accounting and the emotional and personal characteristics of students' psychological health in the process of their educational and professional activities in higher school.

\footnotetext{
25 Arslan S. Social emotional learning and self -regulation: The mediating role of critical thinking. International Journal of Learning and Change. 2018. 10(2), p. 101-112.

26 Arslan S. Social emotional learning and self -regulation: The mediating role of critical thinking. International Journal of Learning and Change. 2018. 10(2), p. 101-112.
} 
Thus, the results of the analytical work done allow us to state that it is legitimate to speak about certain outlines of the theory of psychological health of a personality during early adulthood, which corresponds to student age. The self-reflection of the experience of professional activity in higher school contributes to the direction of the systematization process of empirical studies established by psychologists, which contain new psychological facts regarding the uniqueness of the emotional component of the psychological health of modern students. Let us characterize some of them in the context of two aspects. The first one reflects the aggravation of the psychological health problem of modern student youth, universally recognized by researchers, and actualizes the importance of psychological support for the development process of the indicated integrative personality traits and the conditions of higher education. The result of the empirical study ${ }^{27}$ proved a non-linear relationship between the level of psychological resource of a modern student's personality and identity status ("achieved", "moratorium", "diffuse"), as well as a direct relationship between his or her ability to restore their own resources and positive feelings experienced in communication.

The fact of slow students 'psychological health development has been established $^{28}$, which actualizes the need for systematic support of this process in higher school conditions, in particular, through the use of thinking tools via metaphors (analogy, comparison, "history methods", etc.), such as - "Imagine your psychological health. What does it resemble? Why do you think so?".

According to the experimental data that the researchers obtained, the second aspect of the problem is highlighted - the weight of the emotional component of the psychological health of modern students is increased, which is due not only to the dual nature of emotional phenomena (after all, emotions cannot be reduced to subjective emotional experiences of individuals). Thus, as a result of an empirical study, it was established: $18 \%$ of students of some higher educational institutions in Lviv have inherently high indicators precisely in the context of the scales "emotional psychological problems". According to Canadian researchers' data, every

\footnotetext{
27 Штепа О.С. Особливості психологічної ресурсності осіб 20-25 років з різним статусом ідентичності // Наука і освіта. - 2013. - № 7. - С. 204-208.

28 Токман А.А., Немченко Н.В. Психологія способу життя: Навч.пос. - Ч. І. - К.: Дп Вид. Дім «Персонал», 2015. - 344 с.
} 
sixth student at Queen's University was diagnosed with "depression"29. There is evidence that every third student of Sumy State A. Makarenko University has a low personal potential, which testifies, in particular, to the inclination to emotional lability.

Our multiyear psychological observations coincide with the conclusions of some foreign researchers regarding the fact that the beginning and end of the academic semester in higher school is the most risky with respect to the negative consequences associated with students' stress.

We share the opinion of those scientists (in particular, of D. Goleman) who from a new angle evaluate the relevance of the basic meaning of the "emotional factor" in a psychologically healthy person, contained in the philosophical heritage of ancient Greek thinkers. So, it is advisable to consider the context of Socrates's statement "Know yourself" not emotional intelligence but the fact of awareness of one's own feelings when they arise. As for Aristotle's research of the meaning of "decent life" in his work "The Nicomachean Ethics", it should be emphasized that it consists precisely in teaching people to manage their emotional lives with the help of intelligence; moreover, according to Aristotle, the point is not in emotionality, but in the appropriateness of emotions and their expression.

So, it is advisable to understand psychological health (in terms of quality) as the ability of a person to possess his or her own emotional sphere, the introduction of the natural nature of behavior, where there is no place for unbalanced mental activity. We are talking about a person's ability to understand, realize and control mental activity already at a young age, in particular due to training the dynamics of mental processes and the possession of the emotional sphere.

\section{CONCLUSIONS}

In modern conditions of increasing information pressure on the personality, aggravation of crisis phenomena in the sociocultural life of a person and the critical condition of the environment, the whole range of problematic issues related to psychological health is significantly actualized at all the stages of ontogenesis (in Greek ontos - being, essence and genesis

\footnotetext{
${ }^{29}$ Lessard F.E. (2016) Enquete sur la sanre psychologique etudiante Montreal: Federation des associations etudiantes du campus de l'universite de Monreal, 129 p.
} 
- origin - the process of a human body individual development throughout life. It is said about a protective-compensatory potential of the personality, when sensory hyper stimulation occurs at all levels of perception of the surrounding world. The aforementioned increases the significance of the value-based relationship, first of all, of a young person to his own health in the psychological sphere, because the imperative of values - part of a person's life - has a direct connection with its openness to the "outside world and inner experience". Therefore, it is important, in particular, in the student years, to acquire tools to enrich the value attitude to psychological health. Given that it is the emotional state "directly" and "now" that is a "snapshot of a person's health", the deepening of scientific ideas about the emotional and personal characteristics of a student's psychological health is becoming extremely acute.

The theoretical analysis of scientific approaches to the knowledge of the emotional and personal characteristics of the students' psychological health allows us to expand our scientific ideas about the psychological laws and mechanisms of personal health in the psychological field. The prospects of scientific research lie in the plane of model development which directs the student's self-regulation process in terms of motivational and emotional levels, as well as the phasing of the deployment of educational and professional activities. By taking into account the emotional and personal component of psychological health, it becomes possible to predict the positive dynamics of individual health in the psychological sphere.

\section{SUMMARY}

The problem of the vitality of a modern young person has been raised, where his or her psychological health is an important marker. Health, as the basic concept of this phenomenon, is quite actively studied in the plane of interdisciplinary scientific knowledge. This is due, first of all, to the scientists' attempt to investigate the essence of the outlined phenomenon, taking into account its multidimensionality, since it is a question of health, both physical, psychological, spiritual, and social. But, despite the significant explanatory value that is inherent in the psychological originality of a certain phenomenon, this aspect is still on the periphery of scientific research. Such angle of understanding the personality's psychological health is becoming extremely acute in the context of 
scientific discussion which is taking place now regarding such "polar trends" that (O. Asmolov, O. Shekhter, O. Chornoryzov) specialization and universalization of cognition are considered.

The study and generalization of the scientific fund on the research problem shows that at present such powerful research concepts as medical, biomedical, biosocial, value and social have developed. Constructiveness, in particular the latter, has already been recognized in the framework of the subject specifics of experimental psychology, developmental psychology, social psychology, health psychology, and educational psychology. The legitimacy of the phenomenology of health in relation to the construct "the individual meaning of life" has been proved, to study the problems of health in terms of understanding the dynamism of a healthy state and interpretation as a person's ability to "optimal practicality, social activity with a maximum life expectancy" (V.Kazacheyev). It has been established that among modern scientists the position dominates, according to which it is advisable to study the personality's psychological health in terms of the reserves of adaptive capabilities of particular profession representatives.

It has been ascertained that basically scientific ideas have been formed about the scientific status of the concepts of " mental" and "psychological health", about the interpretation of psychological health as a dynamic process, about the appropriateness of linking a person's psychological illness to the choice of a passive life strategy, about the legality of determining common criteria for a person's psychological health regardless of his or her age identity.

As a result of the analytical work, a circle of problematic issues requiring scientific understanding has been outlined. At the same time, taking into account the methodologically worthwhile observation by A. Maslow that the trajectory of "movement" in the psychological health of a personality has a line in the direction of "approaching social harmony".

\section{REFERENCES}

1. Асмолов А.Г., Шехтер А.Д., Черноризов А.М. Что такое жизнь с точки зрения психологии: историко-эволюционный подход к психофизической проблеме. Вопросы психологии. 2016. № 2. С. 3-23.

2. Бочавер А., Ступак P. XXIV Европейская конференция по психологии здоровья «Здоровье в контексте». Психологический журнал. - М.: Наука, 2011. Т. 32, вип. 2. С. 116-118. 
3. Вилюнас В.К. Психология эмоциональных явлений - М.: Издво МГУ, 1976. - 143 с.

4. Гаврилюк I. Емпірична експлікація суверенності психологічного простору в показниках соціального контролю особистості // Психологічні перспективи. - Вип. 33. - Луцьк, 2019. - С. 49-65.

5. Гоулман Д. Эмоциональный интеллект: пер.с англ. А.П. Исаевой. - М.: АСТ: Астрель, 2011. - 478 с.

6. Данчева Т. Д. Типология психологического здоровья личности // Наука і освіта, 2012. - № 3. - С. 50-54.

7. Ермолаева М.В. Психология развития : учебное пос. - 3-е издание, стереотипное. - Москва : МПСИ ; Воронеж : МОДЭК, 2006. $376 \mathrm{c}$.

8. Завгородня О.В. Питання збереження психологічного здоров'я: визначення, критерії, умови збереження. 2006. № 3(52). С. 87-96.

9. Карпенко В., Миколайчик М, Войтенко В., Мединська Ю. Сучасний стан психічного здоров'я студентської молоді : емоційна, міжособистісна та рольова сфери // Практична психологія та соціальна робота. - 2012. - № 11. - С. 2-8.

10. Кікінеджі С. Гендерна ідентичність в онтогенезі особистості: монографія. - Тернопіль: Навч.книга-Богдан, 2011. - 400 с.

11. Кириленко Т. Емоційна сфера особистості: вектори вивчення // Вісник Київського нац. ун-ту ім. Т. Шевченка. Психологія. 2018. - № 1 (8). - C. $26-29$.

12. Кремень В.Г. Освіта має визначити розвиток духовності й культури // Креативна педагогіка. - 2011. - № 4. - С. 11-12.

13. Максименко С. Д. Генезис существования личности - К.: Издво ООО «КММ», 2006. -240 c.

14. Маслоу А. Психология бытия. - К.: Ваклер, 1997. - 304 с.

15. Прохоров А.О., Валиуллина М.Е., Габдреева Г.Ш., Гарифуллина М.М., Менделевич В.Д. Психология состояний: Уч. пос. / Под ред. А.О. Прохорова. - М.: Изд-во «Когито-центр»$623 \mathrm{c}$.

16. Психология здоровья / Под ред. Г.С.Никифорова. СПб: Питер, 2003. 607c.

18. Роджерс К. Искусство консультирования в терапии / Пер. с англ. Кондрашова О.И. и др. - Москва: Апрель Пресс: Эксмо, 2002. $976 \mathrm{c}$. 
19. Рубінштейн С.Л. Проблеми загальної психології. - М.: Педагогіка, 1973. - 424 с.

20. Токман А.А., Немченко Н.В. Психологія способу життя: Навч.пос. - Ч. І. - К.: Дп Вид. Дім «Персонал», 2015. - 344 с.

21. Хухлаева О.В. Психология развития: молодость, зрелость, старость. - М.: Изд-ий центр «Академия», 2002. - 208 с.

22. Чебикін О.Я. Становлення емоційної зрілості особистості: монографія / О.Я. Чебикін, І.Г. Павлова. - Одеса: СВД Черкасов, 2009. $-230 \mathrm{c}$.

23. Штепа О.С. Особливості психологічної ресурсності осіб 20-25 років з різним статусом ідентичності // Наука і освіта. - 2013. № 7. - C. 204-208.

24. Шувалов А.В. Гуманитарно-антропологические основы теории психологического здоровья. Вопросы психологии. 2004. № 6. C. $18-33$.

25. Arslan S. Social emotional learning and self-regulation: The mediating role of critical thinking. International Journal of Learning and Change. 2018. 10(2), p. 101-112.

26. Lessard F.E. (2016) Enquete sur la sanre psychologique etudiante Montreal: Federation des associations etudiantes du campus de l'universite de Monreal, $129 \mathrm{p}$.

Information about the author: Kichuk A. V. $\operatorname{Dr}(\mathrm{PhD})$ of Psychological Sciences, Associate Professor, Department of General and Practical Psychology of the Izmail State University of Humanities 